NBER WORKING PAPER SERIES

\title{
TERMS OF TRADE, EXCHANGE RATES \\ AND LABOR MARKETS ADJUSTMENT \\ IN DEVELOPING COUNTRIES
}

Sebastian Edwards

Working Paper No. 2110

NATIONAL BUREAU OF ECONOMIC RESEARCH

1050 Massachusetts Avenue

Cambridge, MA 02138

December 1986

This is a revised version of a paper presented at the Wor ld Bank's Conference on Adjustment of Labor Markets in LDCs to External

Changes: 1970-1985, Washington, DC, June 26-27, 1986. I am indebted to Ruth Klinov, Assar Lindbeck and Al Harberger for helpful comments. Financial support from the National Science Foundation through Grant \#SES 8419932 is gratefully acknowledged. The research reported here is part of the NBER's research program in International Studies. Any opinions expressed are those of the author and not those of the National Bureau of Economic Research. 
Terms of Trade, Exchange Rates and Labor Markets Adjustment in Developing Countries

\begin{abstract}
This paper uses three models of a small open economy to analyze the effects of terms of trade and exchange rate changes (i.e. devaluations) on labor market adjustment. First, a three goods (exportables, importables, non-tradables), four factors model is developed and used to investigate how an exogenous worsening of the international terms of trade affect labor allocation and wages. Second, a more traditional three goods, two factors model is used, and its results are compared to those of the first case. The analysis is carried out under alternative assumptions regarding wage flexibility: full flexibility, economy-wide (real) wage rigidity, and sector specific real wage rigidity. Finally, a three final goods model with imported intermediate inputs is used to investigate the effects of devaluations on aggregate and sectoral employment. Here the conditions under which a devaluation will be contractionary (i.e. will result in a reduction of employment) are determined.
\end{abstract}

Sebastian Edwards Department of Economics UCLA

$405 \mathrm{Hilgard}$ Avenue Los Angeles, CA 90024 (213) 825-5304 


\section{Introduction}

The purpose of the present paper is to provide an analysis of the interaction between terms of trade changes, exchange rates (broadly defined) and labor markets in developing countries. The discussion focuses on labor markets adjustments and emphasizes the role of some rigidities that preclude it to adjust smoothly to shocks stemming from the external sector (i.e., terms of trade and exchange rates shocks). By necessity a paper like this has to be selective; the topic is just too broad to be fully covered in one (reasonably long) piece. Moreover, the discussion presented here is carried out mainly from the point of view of the international economics literature; it surveys the way in which this literature can contribute to our understanding of how labor markets behave. It also points out some of that literature's weaknesses and suggests ways in which the traditional trade models could be refined to deal in a more adequate way with problems related to labor market adjustments.

The paper is organized in the following form: Section II uses a three sector (exportables, importables and nontradables), four factors (labor and capital specific to each sector) trade model to analyze how the labor market adjusts to exogenous shocks on commodities relative prices. The analysis also considers the case when capital is allowed to adjust across sectors. In Section III this model is used to analyze how economy wide and sector specific wage rigidities affect labor market adjustment to exogenous shocks. In the tradition of the international trade literature, the model of Sections II and III condsider only final goods. This, of course, is in many ways a limitation, since much of the world's trade corresponds to intermediate imports. In Section IV, however, the role of imported 
intermediate imports is considered. Here the three goods four factors model of Section II is extended. It is assumed that nontradables or home goods (only) use an imported intermediate import. In addition it is assumed that an economy wide minimum wage results in initial unemployment. The analysis then focuses on how aggregate and sectoral unemployment is affected by a nominal devaluation. In particular, this discussion focuses on the contractionary devaulation issue, investigating whether devaluations reduce employment. Finally, Section $\mathrm{V}$ contains the conclusions.

\section{Terms of Trade, Tariffs, and Labor Market Adjustment in the Open Economy}

This section deals with the simple analytics of the interaction between commodity relative prices and labor market adjustment in a small open economy. For this we use a fairly standard international trade model with three final goods - - importables, exportables, and nontradables - - and we look at both the long-and short-run labor market reaction to a terms of trade shock. The discussion is carried out under two alternative assumptions regarding wages: full flexibility and the existence of a minimum wage. It is assumed that in the short run capital is sector specific, while labor can move freely across sectors; in the medium-and long-run, however, both capital and labor can move across sectors. Consequently, depending on whether we deal with the short-or medium-run we have a three goods, four factors model, or a three goods, two factors model. In order to simplify the discussion, throughout most of the analysis we follow the international trade tradition and ignore issues related to capital accumulation. In the first part of the paper (Sections II and III), we also ignore the existence of imported intermediate inputs. In section IV below, however, a model with imported intermediate inputs is fully 
developed.

The analysis presented here is largely positive. The discussion traces in detail the effects of an improvement in the terms of trade brought about by a decline in the world price of imports. The results however are very similar for the case of policy induced changes in import tariffs. Naturally, the case of a worsening of the terms of trade is exactly the opposite of what is discussed here.

\section{1 The Economy Under Consideration}

Assume the case of a small country that produces three goods: exportables $(\mathrm{X})$, importables $(\mathrm{M})$ and nontradables (N). Production is carried out using capital and labor. Production functions have the conventional properties and it is assumed that in the short-run capital is sectorspecific, with labor being perfectly mobile between the three sectors. Following the traditional international trade literature, it is assumed that the quantities available of each factor are given; their supplies are completely inelastic. 1

Imports are initially subject to a tariff, and external borrowing is not allowed. (This assumption may be easily relaxed. See Edwards and van Wijnbergen 1986b). With respect to the labor market, it will initially be assumed that it is free of distortions. However, the consequences of assuming the existence of a minimum wage, which is binding in the short-run, will be investigated in section III below. It is intially assumed that the domestic capital market is free of distortions, with the real rates of

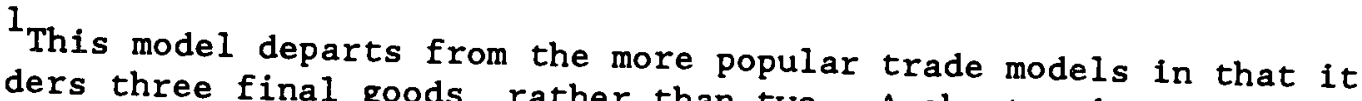
tional trade model, however, is that it ignores imported intermediate specific models see, for example Jones 1971 in Section IV below. On sector1982; Neary 1978a,b, 1982, Edwards 1986. 
return on capital being equalized in the long-run, across sectors. The tariff proceeds are returned to consumers via lump sum transfers. Regarding factor intensity, it will be assumed that importables have the highest capital/labor ratio, nontradables have the next highest ratio, and exportables are labor intensive. This assumption is possibly the most appropriate for the case of the developing countries; moreover this assumption assures us that the system is stable under sector specific wage rigidity (Neary 1981).

II.2. Terms of Trade Shocks. Relative Prices and Structural Adjustment In this section the effects of a reduction in the world price of the country's importables are investigated. It is assumed, for analytical convenience, that initially there are no quantitative restrictions (or that they have been already replaced by tariffs), and that the nominal exchange rate is fixed and equal to one. As noted, it is also assumed that capital is sector specific in the short-run, while it can freely move between sectors in the long-run. The discussion will first deal with long-run effects. Then, the short-run effects and the transition towards the longrun will be discussed. The analysis will concentrate on the behavior of goods prices, employment allocation across sectors, wage behavior and production. In the tradition of standard international trade models it is initially assumed that there is no unemployment. This assumption, however, is relaxed later.

\section{II.2.1 Long-Run Effects}

In this class of models of a small economy with three goods (importables, exportables and nontradables), and the usual competition assumptions in the medium and long runs, when all factors can move freely across sectors, domestic prices of the three final goods are fully deter- 
mined (under non-specialization) by world prices, technology and tariffs. Equilibrium can be described in the following way: with no specialization in production, world prices of exportables and importables (plus the tariff) determine the rewards to both factors of production; these rewards, on their turn and under the assumption of competition, determine the price of nontradables. Demand considerations for nontradables determine total output of nontradables and total factors used in their production. This leaves a certain amount of factors that is used in the production of exportables and importables in a traditional Heckscher-Ohlin (H-O) fashion. In the rest of the analysis the price of exportables will be taken to be the numeraire (i.e., $P_{X}=1$ ).

The effect of an exogenous shock that reduces the international price of $M$ on factor rewards and the relative price of nontradables $P_{N}$ can be analyzed using Figure 1, which is the dual to the well-known Lerner-Pearce diagram. ${ }^{2}$ The initial equilibrium is given by the intersection of the three isocosts $M M, X X$, and $N N$. These curves present the combinations of wages and rental rates of capital that result in a constant cost of producing these goods at the existing technology (see Mussa 1979). The slopes of these curves are equal to the capital labor ratio, and as may be seen in Figure 1, correspond to our assumptions of relative capital intensities. Initially equilibrium is obtained at $A$ with a wage rate (relative to

2 This diagram, and the whole discussion that follows assumed that both the three goods are produced) price change there is no specialization (i.e., context of relative pricur discussion, where the exogenous shocks is a change in the other models of exportables to importables. It should be noted that in nonspecials of 3 goods and two factors it is not so easy to rule out nonspecialization. This is the case, for example, if the importables and is only possible if the relative single good (tradable). This, of course, is only possible if the relative price between $X$ and $M$ does not change. 
exports) equal to $W_{0}$ and a rental rate equal to $r_{0}$.

The reduction of the price of $M$ will result in a leftward shift of the MM curve towards $M^{\prime} M^{\prime}$. This is because now, in order to maintain equilibrium between domestic costs and the world price of importables, plus the tariff, lower combinations of wages and rental rates will be required. New long-run equilibrium will be obtained at $B$ where the new $M^{\prime} M^{\prime}$ curve intersects the $\mathrm{XX}$ curve. The NN curve will, consequently, shift back until it intersects the other two curves at B. Naturally, this backward shift of the NN curve reflects a reduction in the equilibrium price of nontradable goods. As the Stolper-Samuelson theorem indicates, the reduction of the price of $M$ in an economy where exportables are labor intensive, will result in higher wages and lower rental rates $\left(i . e ., W_{1}>\right.$ $\mathrm{w}_{0}$, and $\left.\mathrm{r}_{1}<\mathrm{r}_{0}\right)$

The production side of the model, as well as the factors' adjustment, can be analyzed using a three goods Edgeworth-Bowley box as developed by Melvin (1968). Figure 2 illustrates the case considered here where exportables are the most labor intensive good. In this diagram nontradables isoquants are drawn from origin $O_{N}$. At the initial prices the nontradable goods market clears at a level of production given by isoquant ${ }^{N_{N}} 0^{\text {The }}$ capital-labor ratio in nontradables production is given by the slope of $\mathrm{O}_{\mathrm{N}} \mathrm{O}_{\mathrm{M}}$. Production of exportables is measured from $\mathrm{O}_{\mathrm{X}}$, and that of importables by distance $O_{M} R$. In equilibrium the slope of ${ }^{N_{N}}$ isoquant at $O_{M}$ equals the slopes of the corresponding isoquants for exportables and importables, which are tangent at $R$.

Since the reduction of the price of $M$ generates an increase in the wage rate relative to the rental rate all three sectors will now become more 
Figure 1

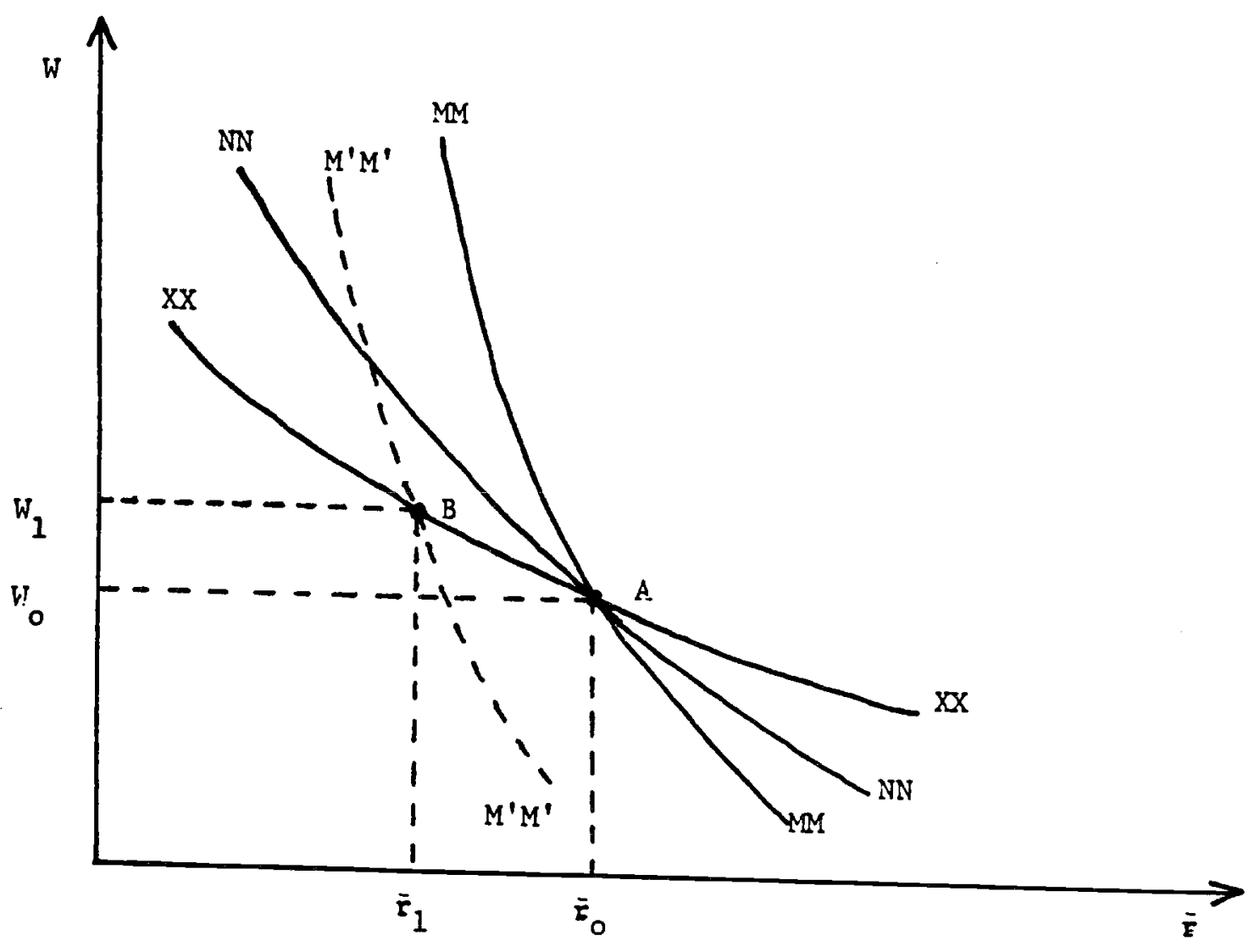


Figure 2

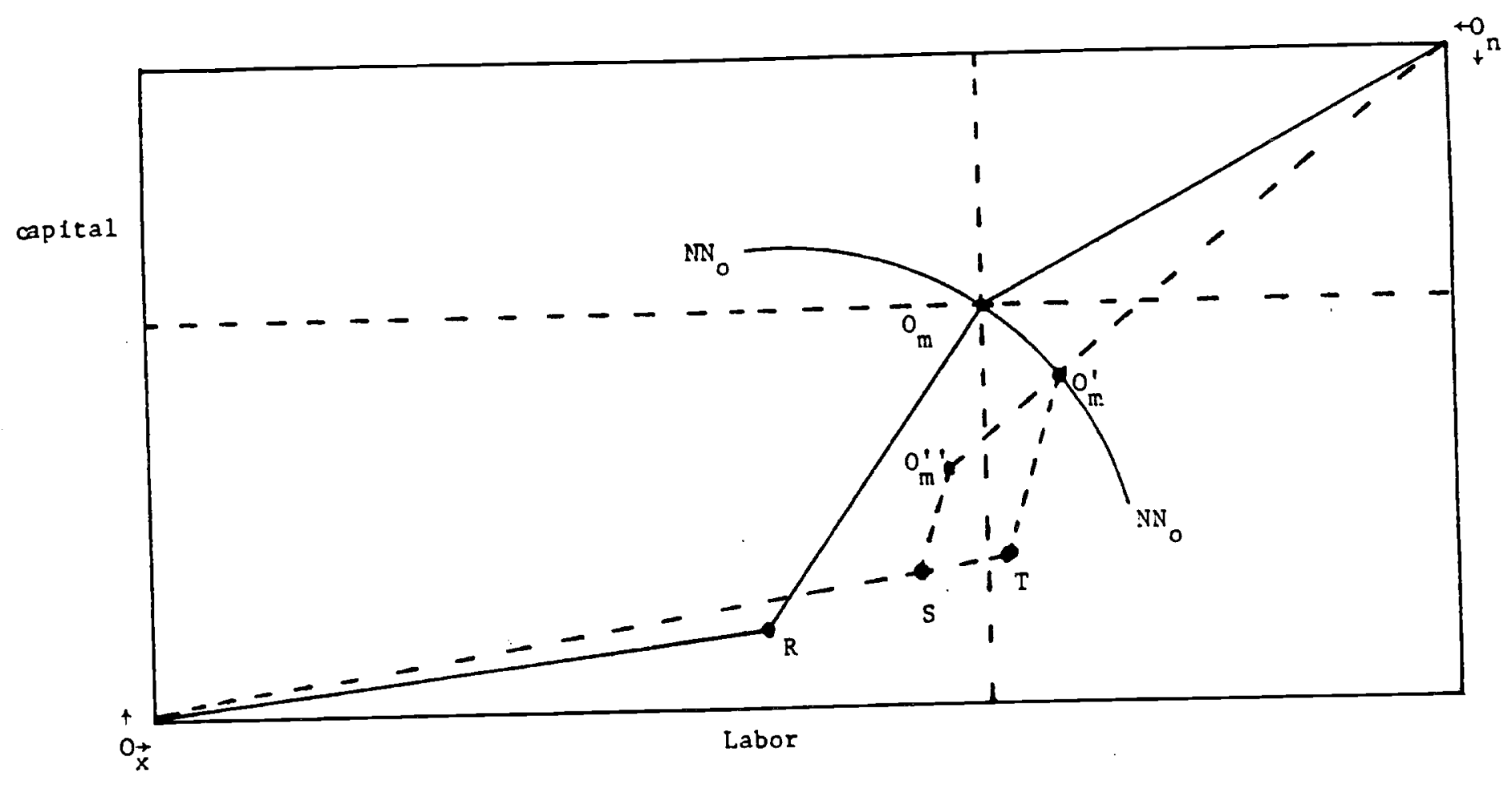


capital intensive. This is shown in Figure 2, where the dashed rays depict the new (after $P_{M}^{*}$ reduction) capital/labor ratios. However, in order to determine the new equilibrium it is necessary to know what will happen to the demand of nontradables, as a consequence of the reduction in the world price of $M$.

Where will the new equilibrium point for the production of nontradables be located? If total output of $\mathrm{N}$ remained constant, the new equilibrium would be on the $\mathrm{N}_{0} \mathrm{~N}_{0}$ isoquant. However, given the assumption regarding capital-labor ratio and the initial $\mathrm{NN}_{\mathrm{O}}$ isoquant, at point $\mathrm{O}_{\mathrm{M}}^{\prime}$. Production of importables will be reduced to $\mathrm{O}_{\mathrm{M}}^{1} \mathrm{~T}$, and production of exportables will increase to $M_{X} T$. This result was obtained under the assumption that the quantity demanded of nontradables was not affected by the reduction of the world (and domestic) price of $M$. In general, however, this will not be the case. Moreover, given our assumptions regarding capital/labor intensity, it is expected that the demand for nontradables will increase as a result of improvement in the terms of trade. There are two reasons for this: (a) As shown in Figure 1, after the exogenous shock the (relative) price of nontradables will decline, producing a substitution effect in demand towards nontradables; and (b) the improvement in the terms of trade will generate a positive income effect, as national income at international prices increases, which will also have a positive effect on the quantity demanded of $\mathbf{N}$. With a higher demand for nontradables, long-run equilibrium in Figure 2 will be on the new capital-labor ratio ray to the left of the $\mathrm{NN}_{\mathrm{O}}$ isocost on a point such as $\mathrm{O}_{M}^{\prime \prime}$, with production of exportables being equal to $\mathrm{OS}$, production of importables having been reduced to $\mathrm{O}_{\mathrm{M}}^{\prime \prime} \mathrm{and}$ production of nontradables being equal to $O_{N} O_{M}^{\prime \prime}$.

In summary, under our assumptions on capital intensities, the effects 
of an improvement in the terms of trade, when all factors can move freely across sectors, will be: (i) Prices of nontradables, relative to exportables will fall; (ii) Wages, relative to all goods, will increase; (iii) The real rate of return on capital, relative to all goods, will decrease; (iv) Production of exportables will expand; (v) Production of nontradables will expand; and (vi) Production of importables will decline. These equilibrium price movements give us information on potential adjustment problems emerging from the shocks stemming from abroad. If, for example, under fixed exchange rates nominal prices on nontradables are rigid downward we may have a problem. This is because according to (i) $\mathrm{P}_{\mathrm{N}} / \mathrm{P}_{\mathrm{X}}$ will have to decline in order to maintain equilibrium. Since under the small country case the world price of exports $\mathrm{P}_{\mathrm{X}}^{*}$ is given, the nominal price of nontradables would have to decline to attain equilibrium; under nominal price rigidity this will not happen and unemployment will result. Notice, however, that if real wages are rigid downward, no disequilibrium situation will emerge in the long-run. This is, of course, because according to (ii) real wages will increase in terms of all goods. This, however, will not be the case in the short-run as will be shown below.

It is interesting to note that the discussion presented here can be readily applied to the case of a trade liberalization reform aimed at reducing taxes on imports. The main difference between the case of a policy induced reduction in $P_{M}$ (via a lower import tariff) and the exogeneously generated reduction in $P_{M}$, via a lower $P_{M}^{*}$, resides on the magnitude of the income effect. For the same change in the domestic price of $M$ the exogenous shock generates a higher income effect. See Edwards and van Wijnbergen $(1986 \mathrm{~b}, \mathrm{c})$. 


\section{II.2.2. Short-Run Effects}

This section investigates the short-run effects of the terms of trade shock under the assumption that in the short-run capital is sector specific, while labor can move freely across sections. In that sense the model discussed here can be considered as having three final goods and four factors (capital, labor in $X$, labor in $M$ and labor in N.) ${ }^{3}$

The initial labor market equilibrium situation can be illustrated using Figure 3. In this figure, the horizontal axis measures total labor available in the economy, while the vertical axis depicts the wage rate in terms of exportables, $L_{T}$ is the demand for labor by the tradable goods sectors and is equal to the (horizontal) sum of the demand for labor by the export able sector (which is given by $L_{X}$ in this figure) and the demand for labor of the importables sector. $L_{N}$ on the other hand is the demand for labor of the nontradable goods sector. The initial equilibrium is characterized by a wage rate equal to $W_{O}$, with $O_{T} L_{A}$ labor used in the production of exportables, $L_{A} L_{B}$ labor used in the production of importables and $O L_{B}$ used in the production of nontradables.

There are several differences between this short-run model and the long-run model discussed in the previous subsection. First, since capital is now sector specific," the direct link between tradable goods prices and factors rewards is broken. Stolper-Samuelson theorem does not hold (in the short-run), and the price of nontradables will be determined by the intersection of the demand and supply schedules of these kind of goods.

In the short run, the reduction in the price of $M$, under the

3 three goods case of the viner-Ricards model, then, is an adaptation for a and Mussa (1974). See Edwards (1986) models of Jones (1971), Mayer (1974) (1986b). 
Figure 3

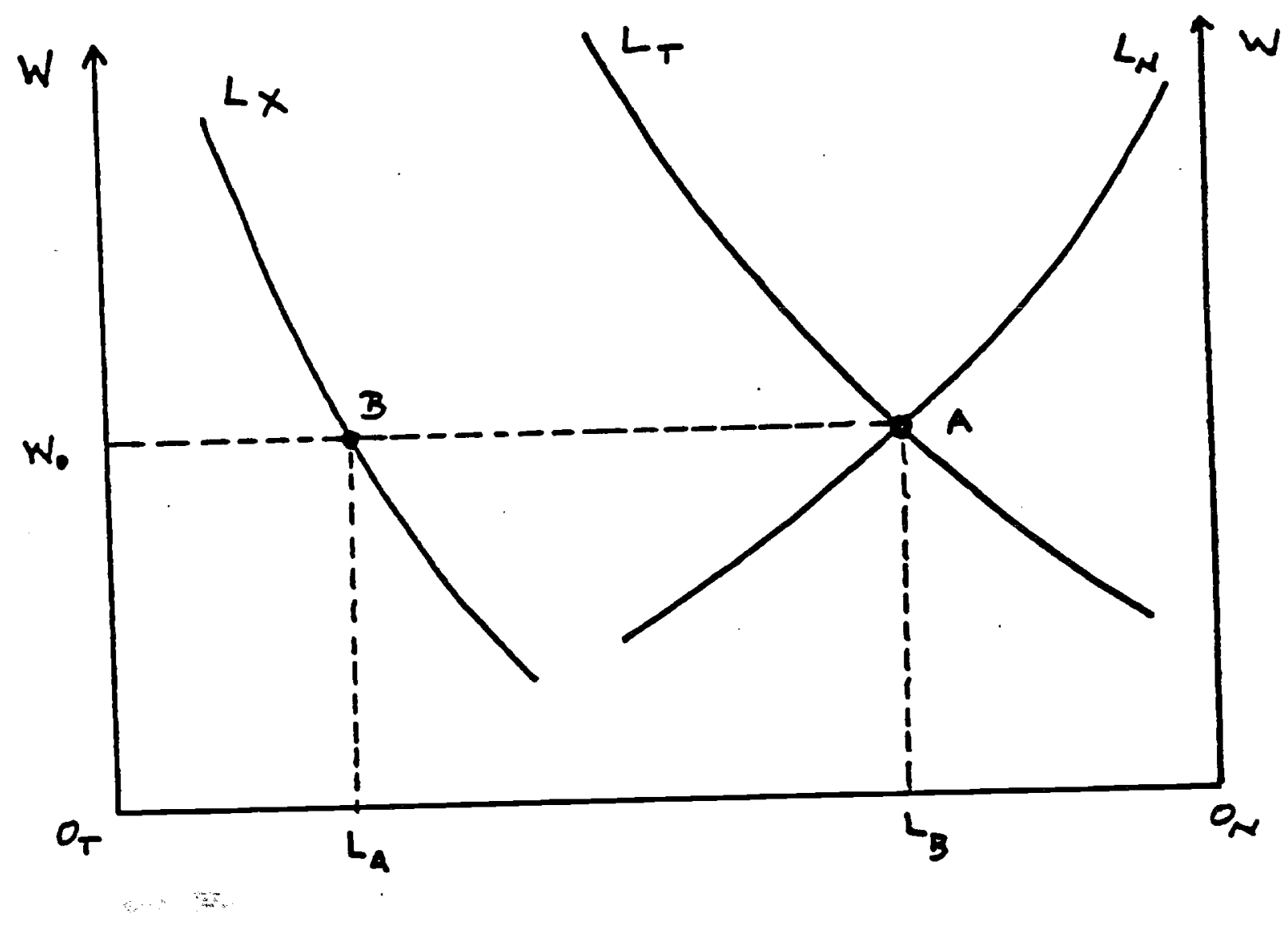

$r$ 
assumption of sector-specific factors, will generate changes both in the domestic price of importables and nontradables (see, for example, Dornbusch 1974, 1980; Edwards 1986). While the domestic price of importables will unambiguously fall, the behavior of the price of nontradables will depend on the assumption regarding substitutability and the magnitude of income effects. Assuming that the three goods are gross substitutes in consumption and production, and that the income effect does not exceed the substitution effect, it can be shown that as a result of the terms of trade improvement the price of nontradables will fall relative to that of exportables and increase relative to that of importables (Edwards 1986).

The labor market adjustment process is illustrated in Figure 4. The reduction in the price of $M$ will result in a lower domestic price of importables, generating a downward shift of the $\mathrm{L}_{T}$ curve (with the $\mathrm{L}_{X}$ curve constant). In Figure 4 the new $\mathrm{L}_{T}$ curve will intersect the $\mathrm{L}_{\mathrm{N}}$ curve at $R$. However, this is not a final equilibrium situation, since the reduction in $P_{M}^{*}$ will also result in a decline in the price of nontradables (relative to exports). As a consequence, $\mathrm{L}_{\mathrm{N}}$ will shift downward (by less than $L_{T}$ ) and final short-run equilibrium will be achieved at $S$. In this new equilibrium production of exportables has increased - - with labor used by this sector increasing by $\mathrm{L}_{A} \mathrm{~L}_{Q}$. The production of nontradables may either increase or decrease, and production of importables will fall. In the case depicted in Figure 4, labor has moved out of the importables goods sector, into exportables and nontradables sectors.

What has happened to factors rewards in the short-run? Wages have declined in terms of the exportable good (from $W_{0}$ to $W_{1}$ in Figure 4). Also, wages decline in terms of the nontradable good, since the vertical distance between the $\mathrm{L}_{\mathrm{N}}$ and $\mathrm{L}_{\mathrm{N}}^{1}$ curves is smaller than the reduction of 
regure 4

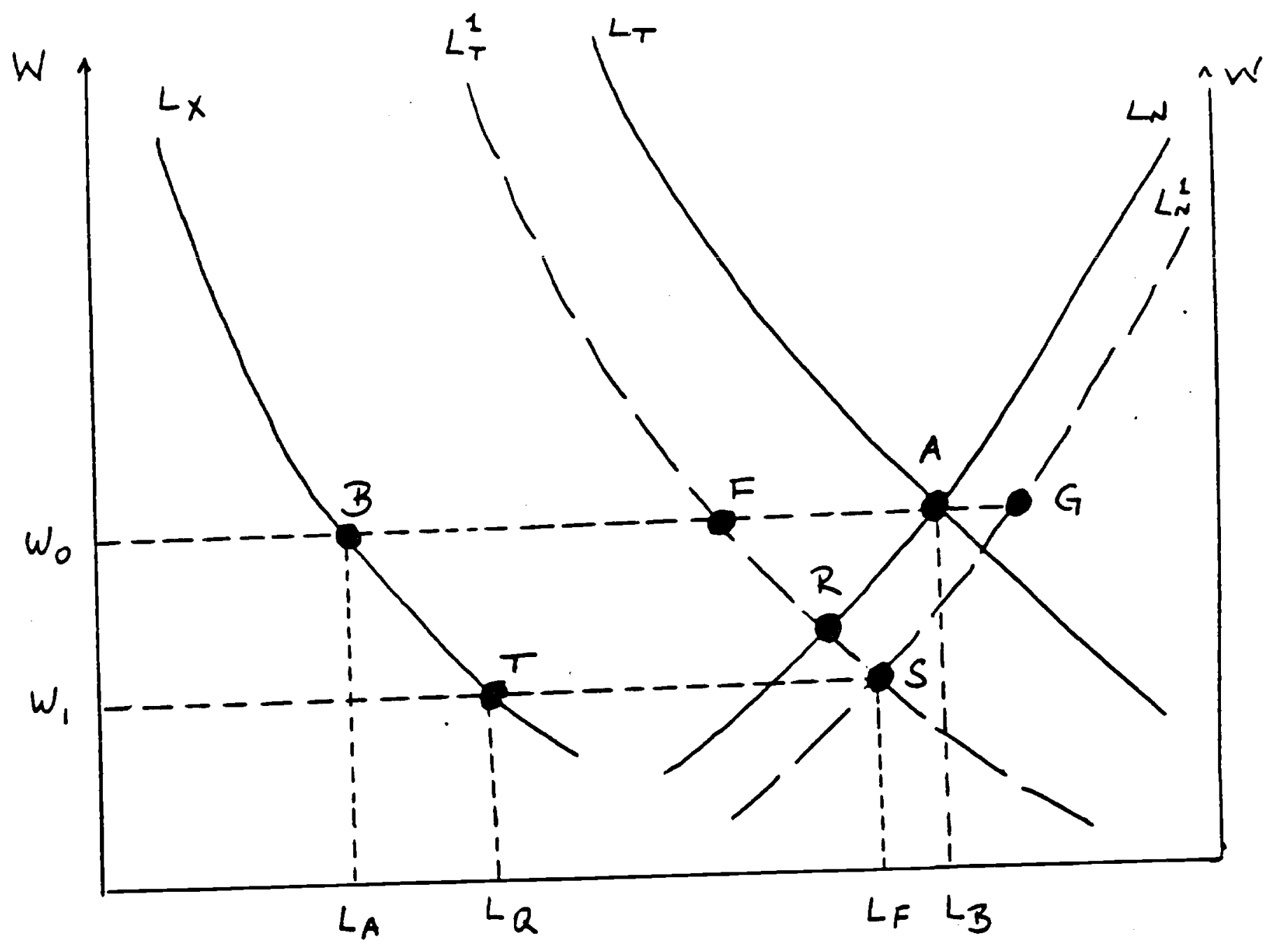


$W$ from $W_{0}$ to $W_{1}$. However, wages increase relative to the importable good, since the domestic price of importables has fallen by more than wages. In the exportables sector, the real returns to capital specific importables and nontradables sector could either increase or decrease. 4

Figure 5 summarizes the adjustment in production of $X, M$ and $N$, when capital is sector specific. The initial (pre-shock) equilibrium is given by points $A$ and $G$, with production of exportables proportional to distance $\mathrm{O}_{\mathrm{X}} \mathrm{A}$, production of nontradables given by isocost $\mathrm{NN}_{\mathrm{O}}$, and production of importables proportional to distance GA. Notice that initially the nontradable goods sector uses ${ }_{{ }_{N}} K_{N}$ capital, the exportables sector uses $O_{X} K_{X}$ capital, and the importables will use the rest $\left(K_{N} K_{X}\right)$. Since in the short-run capital is sector specific these amounts of capital will also be used by each sector after the tariff reform. This means that the new short-run equilibrium points will necessarily lay on the $\mathrm{K}_{\mathrm{N}} \mathrm{K}_{\mathrm{N}}$ and $\mathrm{K}_{\mathrm{X}} \mathrm{K}_{\mathrm{X}}$ lines. The reduction in $\mathrm{P}_{\mathrm{M}}^{*}$ will result in an increase in the use of labor (and thus in production, for given amounts of capital) in the export. ables and nontradables sectors. This is shown in Figure 5 by the movement of the equilibrium points to $B$ and $F$. The new capital-labor ratios are now given by the dashed lines, and as may be seen both the exportable and nontradable sectors become relatively more labor intensive, while the importables sector has become more capital intensive. A comparison of Figures 2 and 5 provides some indication on how the transition period will look like, with factors moving from their post-terms of trade shock short.

${ }^{4}$ Formally, the real return on capital specific to the importable sector will decrease in terms of importables, and could either increase or decrease nontradables sector, its rental Wate respect to capital specific to the could either increase or decrease 
16

Figure 5

Trade Liberalization Effects in the Short-Run

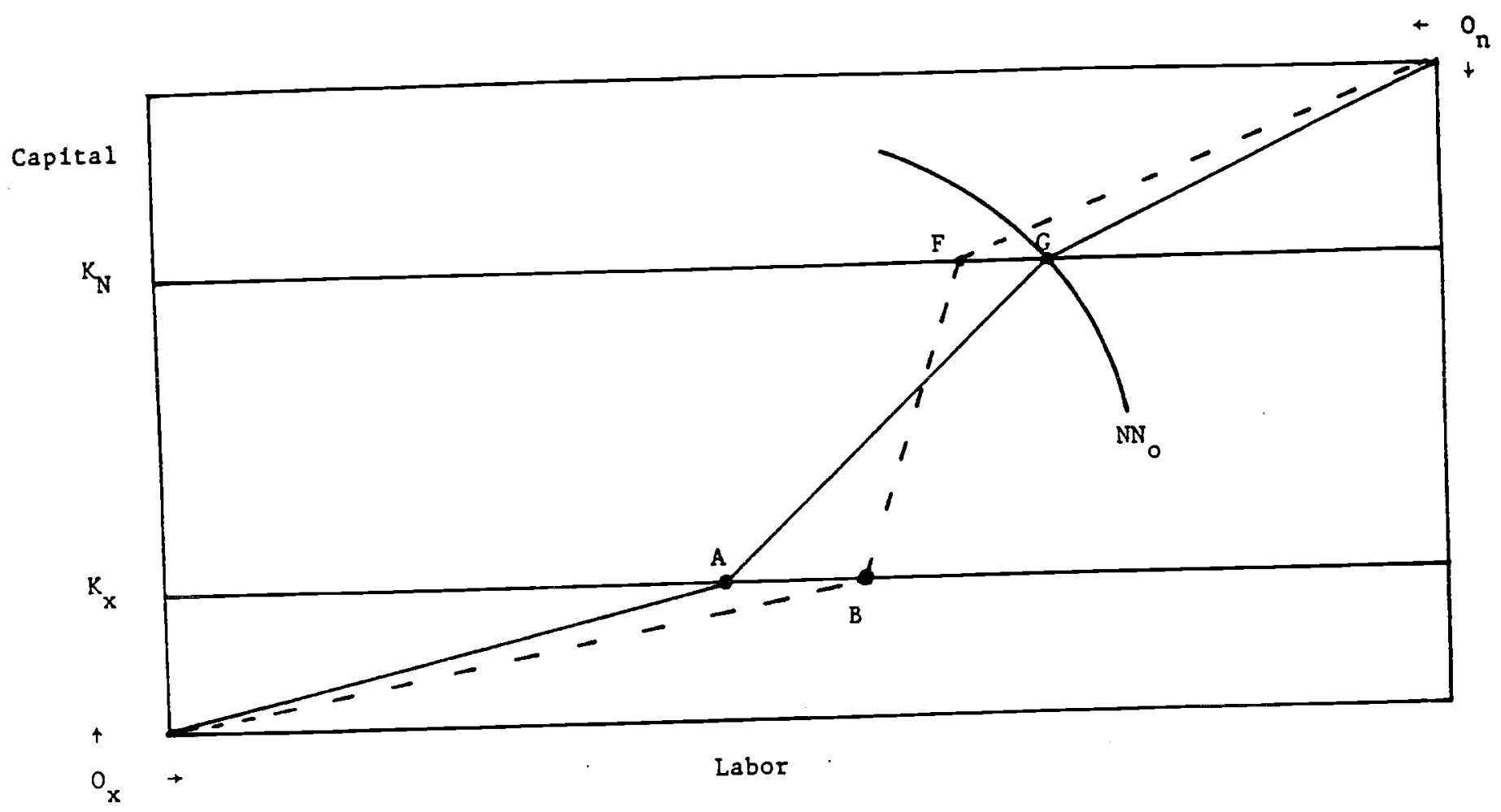


run allocation towards their long-run allocation.

In summary, for the general case with wage flexibility, the short-run effects of an improvement in the terms of trade on production, prices, and factors rewards are the following: (i) Production of exportables

increases; (ii) Production of importables is reduced; (iii) Production of nontradables may increase or decrease; (iv) Wages increase in terms of importables, and decline in terms of exportables and nontradables; (v) The real return of capital in the exportable sector increases relative to all goods; (iv) The real return of capital in the importables sector will decrease relative to the importable good. It could increase or decrease relative to the other good; and (vii) The real return to capital in the nontradables sector will increase relative to nontradable goods, and could either increase or decrease relative to the other two goods.

\section{2.3. The Transition Period After a Terms of Trade Improvement}

The model used in this section assumes that the main differences between short-and long-run effects of a trade liberalization is that in the short-run capital is locked into its sector of origin. As time passes, however, capital will (slowly) move between sectors. In the present model, and in order to simplify the exposition, we assume that the movement of capital does not require the use of resources. However, the analysis could be modified by introducing a "moving industry", which uses labor and some specific factor, as in Mussa (1978).

The transition period will be basically characterized by factors (both capital and labor) moving between sectors, until the new long-run equilibrium (i.e., post-terms of trade shock) capital-labor ratios and level of production are attained. As discussed in Section II.2.1, and as may be seen from Figure 3, in the final long-run equilibrium all sectors will be 
more capital-intensive, with the exportable sector using more capital, in absolute terms; and with the importable sector using less capital in absolute terms than prior to the external shock. As may also be seen from Figure 3 , the nontradable goods sector could use either a larger or small absolute amount of capital than before the reduction in $P_{M}^{*}$.

The nature of factors movements during the transition period can be seen in Figure 6 , which combines Figures 3 and 5 . Initial equilibrium is given by points $A$ and $G$. Short-run equilibrium is given by points $B$ and $F$, while long-run equilibrium will be attained in points $H$ and $C$. In order to avoid cluttering the diagram, only the post-terms of trade improvement capital-labor ratios have been drawn. The arrows between points $B$ and $C$ and $F$ and $H$, respectively, show the way resources will move during the transition. As may be seen in Figure 6, for the particular case considered here, the transition will be characterized by: (i) Capital and labor will move out of the importable goods sector; (ii) Capital and labor will move into the exportable goods sector; (iii) Capital will move into the nontradable goods sector, and labor will move out of the nontradable goods sector.

Table 1 summarizes the movement of resources and factor prices that follow an exogenous improvement of the terms of trade. Column (1) in Panel A depicts the movement of resources in the short-run. Column (2) shows how resources move in the long-run, when compared with the initial situation. This column is a summary of the situation described in the Melvin-EdgeworthBowley box in Figure 3. Finally, in column (3) the movement of resources during the transition period is presented. Panel A of this table is quite revealing, since it clearly points out toward potential sources of labor market disequilibria and adjustment costs following an exogenous shock 


\section{F1gure 6}

Transition After Trade L1beralization

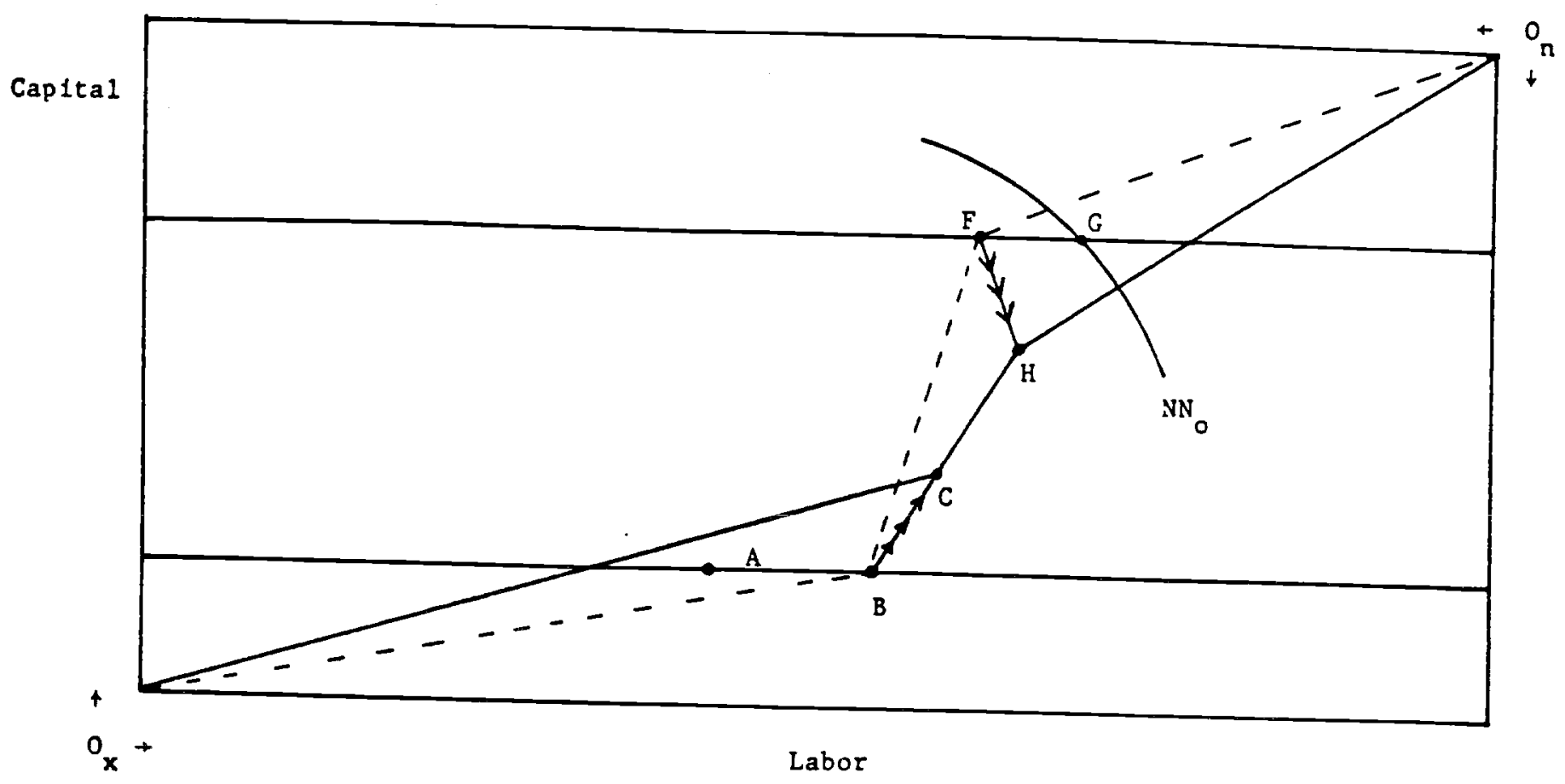


TABLE 1

Short- and Long-Run Resource and Factor Rewards Movements

Following A Positive Terms of Trade Shock

A. Factor Movements

(1)

Short-Run vs.

Sector

Exportables
Importables
Nontradables

B. Changes in Factor Rewards

\begin{tabular}{|c|c|c|c|c|c|c|}
\hline & $r^{a}$ & $\mathbf{w}$ & $r^{b}$ & w & $r^{b}$ & $\mathrm{w}$ \\
\hline Exportables & $\uparrow$ & $\downarrow$ & $\downarrow$ & $\uparrow$ & $t$ & $\uparrow$ \\
\hline Importables & $t$ & $\uparrow$ & $\downarrow$ & $\uparrow$ & $\downarrow \uparrow$ & $\downarrow \uparrow$ \\
\hline Nontradables & $\uparrow$ & $\downarrow$ & $\downarrow$ & $\uparrow$ & $t$ & $\uparrow$ \\
\hline
\end{tabular}

(3)

Long-Run vs . Short-Run (Transition) Initial Situation

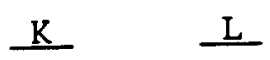

$\underline{\mathrm{K}}$

$\uparrow$

$\downarrow$

$\uparrow$

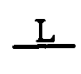

$\uparrow$

$\downarrow$

$\uparrow \downarrow(?)$ $\uparrow$

$\downarrow \uparrow$

$\downarrow$

$\uparrow$

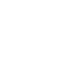


stemming from the external sector. As may be seen, equilibrium will require that labor moves into the nontradable sector in the short run and out of it in the longer run. If, however, there are rigidities this movement of labor in and then out of the importable sector may be quite costly in term of adjustment. This analysis also raises the question largely ignored until now, of the role of expectations in labor market adjustment. If the terms of trade shock is perceived as being only temporary, our short run case will be more relevant.

\section{Terms of Trade Shocks in the Presence of Labor Market Rigidities}

The discussion presented above followed the more traditional models of international trade where all factor prices, including wages, are assumed to be perfectly flexible. That, of course, is a simplifying assumption which does not correspond to reality in many of the LDCs. In most developing countries in fact, there are minimum wage laws, or other types of rigidities, that either affect the whole economy or cover only some parts of it. In the last ten years or so a number of trade models that in fact assume some type of factor price rigidities have been developed (see Brecher 1974a,b; Bruce and Purvis 1984). These models have been useful and have added considerable realism to the analysis. Most of them, however, have concentrated on the case of two goods only. In this section we extend the previous model and discuss the effects of a terms of trade shock under two alternative types of wage rigidities, stemming from the existence of exogenously imposed minimum wages. The analysis will concentrate mainly on 
the short-run case where capital is locked into its sector of origin. 5

\section{III.1 Economy Wide Wage Rigidities}

Consider first the case of an economy-wide minimum wage. Assume, in order to facilitate the diagramatical exposition, that this minimum wage is expressed in terms of exportables, and that its initial level corresponds to that wage that intially corresponds to full employment. That means that before the terms of trade shock, there is no unemployment. While this simplifying assumption greatly facilitates the exposition, it is quite inessential.

It is easy to see from Figure 4 that if wages, expressed in terms of exportables are inflexibly downward and capital is sector specific, unemployment will result as a consequence of the shock that reduces the relative price of $M$. In terms of Figure 4, the magnitude of this unemployment will be equal to distance FG. This is basically a short-run adjustment cost, which will tend to disappear as capital moves between sectors in the medium- and long-run. ${ }^{6}$ In general, in the presence of sector specific capital and wage rigidity, a short-run disequilibrium situation will emerge as a result of the terms of trade shock. The extent of this disequilibrium situation will depend on whether wages are inflexible in terms of exportables, as was assumed above for expository reasons, or if

5 As shown above, under our assumptions regarding capital intensity, in the long run a terms of trade improvement generates an equilibrium increase in real wages. Thus in the long run a minimum wage in real terms will become less binding after an external shock that reduces ${ }_{M}$.

${ }^{6}$ See Neary (1982) and Edwards (1982) for discussions regarding trade liberalization, sticky wages and unemployment. It is interesting to note that an effect of this type can be used to analytically derive short-run output losses following a trade liberalization process, as is done by Khan and Zahler (1983). For a synthesis on this type of literature see the recent comprehensive survey by Neary (1985). 
they are inflexibles in terms of importables or in terms of an index of $M$, $X$ and $N$. The reason for this, of course, is that if wages are inflexible in terms of the importable no unemployment will result since real wages in terms of $M$ go up! If, on the other hand, real wages are inflexible measured in terms of price index, unemployment may result if the weight of importables in the price index is sufficiently small. Edwards (1982) has shown that if the weight of exportables is "sufficiently" large a positive terms of trade shock will indeed result in short run unemployment. A "sufficiently large" weight of exportables is defined as $\alpha>$ $P_{M} F_{L L} /\left(P_{X} F_{L L}+P_{M} F_{L L}\right)$, where $F_{L L}$ is the second derivative of the production function relative to the amount of labor. 7

It is interesting to note that if instead of a terms of trade shock, the decline of $P_{M}$ is due to a tariff reduction liberalization reform, this possible short run unemployment effect may call for a second-best argument for gradual reduction in tariffs. This would be the case, for example, if only the maximum amount of capital that can move across sectors in each period is small compared to the total desired capital reallocation given the relative price changes. 8 However, the first best policy, of course, would be to remove the minimum wage distortion.

What happens in the long run in this case with an economy minimum wage? As time passes capital can move across sectors, and a steady flow of capital out of the importable sector will take place. As shown in section II above, as long as there is no specialization in production, in the long run the Stolper-Samuelson result will hold. When $P_{M}^{*}$ declines, real wages in terms 7 This includes $M$ and $X$ that the wage rate is fixed in terms of an index that ${ }^{8}$ See Edwards (1982). 
of all goods will go up, rendering the preexisting (downward) inflexible real wage redundant. As capital is reallocated out of $M$, there will be forces that will reduce the unemployment created on impact until it completely disappears. In this case unemployment will only be a short run phenomenon. The long run will be characterized by full employment and higher real wages. Naturally, this result would not hold if the terms of trade shock is negative (i.e., increase in $P_{M}$ ). In that case with an economy wide minimum wage, the long run equilibrium would be characterized by positive unemployment.

\section{2 Sector Specific Wage Rigidity}

In most countries, however, minimum wages don't usually cover all sectors, and are generally applied only to the urban sector. The analysis of the labor market adjustment to external relative price shocks in the presence of sector specific minimum wages can get quite complicated. In what follows, we look in detail at the case where the minimum wage applies to the importable sector. This in fact is consistent with the stylized fact that in most developing countries minimum wage legislation cover the manufacturing sector only. Throughout the discussion that follows, and mainly to facilitate the diagrammatical exposition, we maintain the assumption that the minimum wage is expressed in terms of the exportable good. We then briefly discuss the directions in which the analysis is affected when we assume that the minimum wage is expressed in terms of other goods.

Consider now the case of a binding minimum wage in the importables sector only. In order to analyze this case we have to somewhat modify our diagrams; this may appear at first messy but it is actually quite useful. Figure 7 is similar to Figure 3 , except that now we measure total labor used in the importables sector starting from the righthand side origin ${ }_{M}$. The 
FIGURE 7

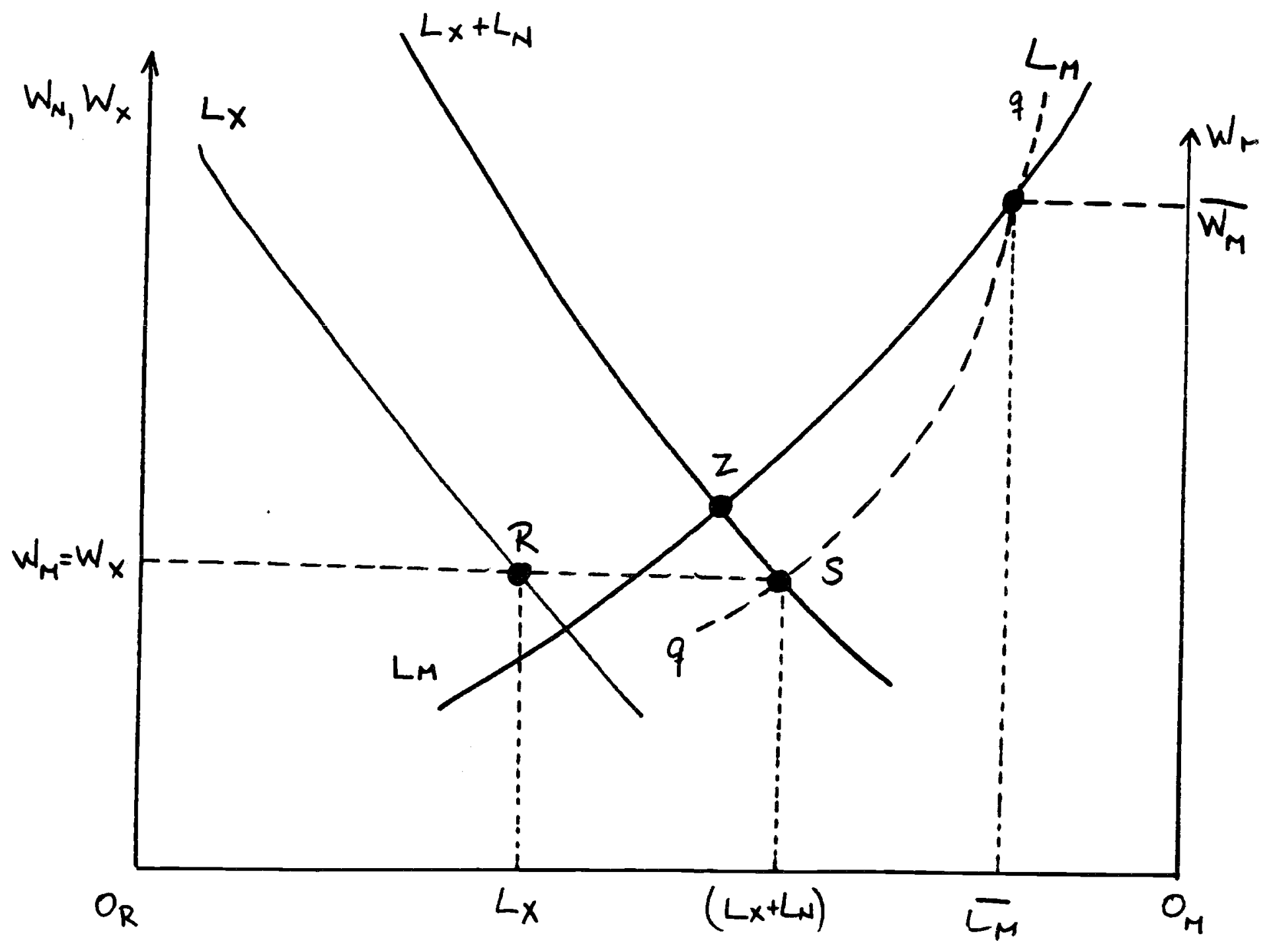


vertical righthand side axis measures the wage rate in the importables sector. The lefthand side vertical axis, on the other hand, measures wages in the other two sectors. The wage rate $\overline{\mathrm{W}}_{M}$ is the minimum wage in the importable sector (i.e., manufacturing); $\overline{\mathrm{L}}_{M}$ is then employment in this sector. Curve qq is a rectangular hyperbole known as the Harris-Todaro locus, along which the following equation is satisfied:

$$
\mathrm{w}_{\mathrm{N}}=\mathrm{w}_{\mathrm{X}}=\frac{\mathrm{L}_{\mathrm{M}}}{\mathrm{L}_{\mathrm{M}}+\mathrm{U}} \overline{\mathrm{W}}_{\mathrm{M}} \text {, }
$$

where $U$ is the equilibrium rate of unemployment. ${ }^{9}$ In the absence of a minimum wage, equilibrium is attained at point $S$. With a minimum wage, however, the intersection of $\left(\mathrm{L}_{\mathrm{X}}+\mathrm{L}_{\mathrm{N}}\right)$ with qq gives us the wage rate in the uncovered sectors, employment in each sector, and total unemployment. ${ }_{\mathrm{R}} \mathrm{L}_{\mathrm{X}}$ is total employment in the exportable sector; distance $\mathrm{L}_{\mathrm{X}}\left(\mathrm{L}_{\mathrm{X}}+\mathrm{L}_{\mathrm{N}}\right)$ measures employment in nontradables; distance $\left(\mathrm{L}_{\mathrm{X}}+\mathrm{L}_{\mathrm{N}}\right) \overline{\mathrm{L}}_{\mathrm{M}}$ is the initial equilibrium level of unemployment; and, as noted, $O_{M} \bar{L}_{M}$ is employment in the covered sector. 10

The short run (i.e., with immobile capital across sectors) effects of a terms of trade shock that reduces the world price of the importable good are illustrated in Figure 8 . As a result of the decline in the world price of

'This formulation, of course, follows from Harris and Todaro's (1970) classical article on migration. See also Harberger (1971). For the use of this discussion in the context of a two sectors economy see Corden and Findlay (1975) and Neary (1981). Notice that for exposition purposes we have assumed that the wage rate in $M$ is fixed with respect to exportables. See Neary (1981) for an illustration of what will happen if this assumption is changed.

${ }^{10}$ Notice that there is an important difference between this type of model of minimum wages where total availability of labor to the economy is given and those models where there is an aggregate upward sloping supply of labor. On this last type of model see A. Cox Edwards (1986), and Edwards and Cox Edwards. (1986). 
27

FIGURE 8

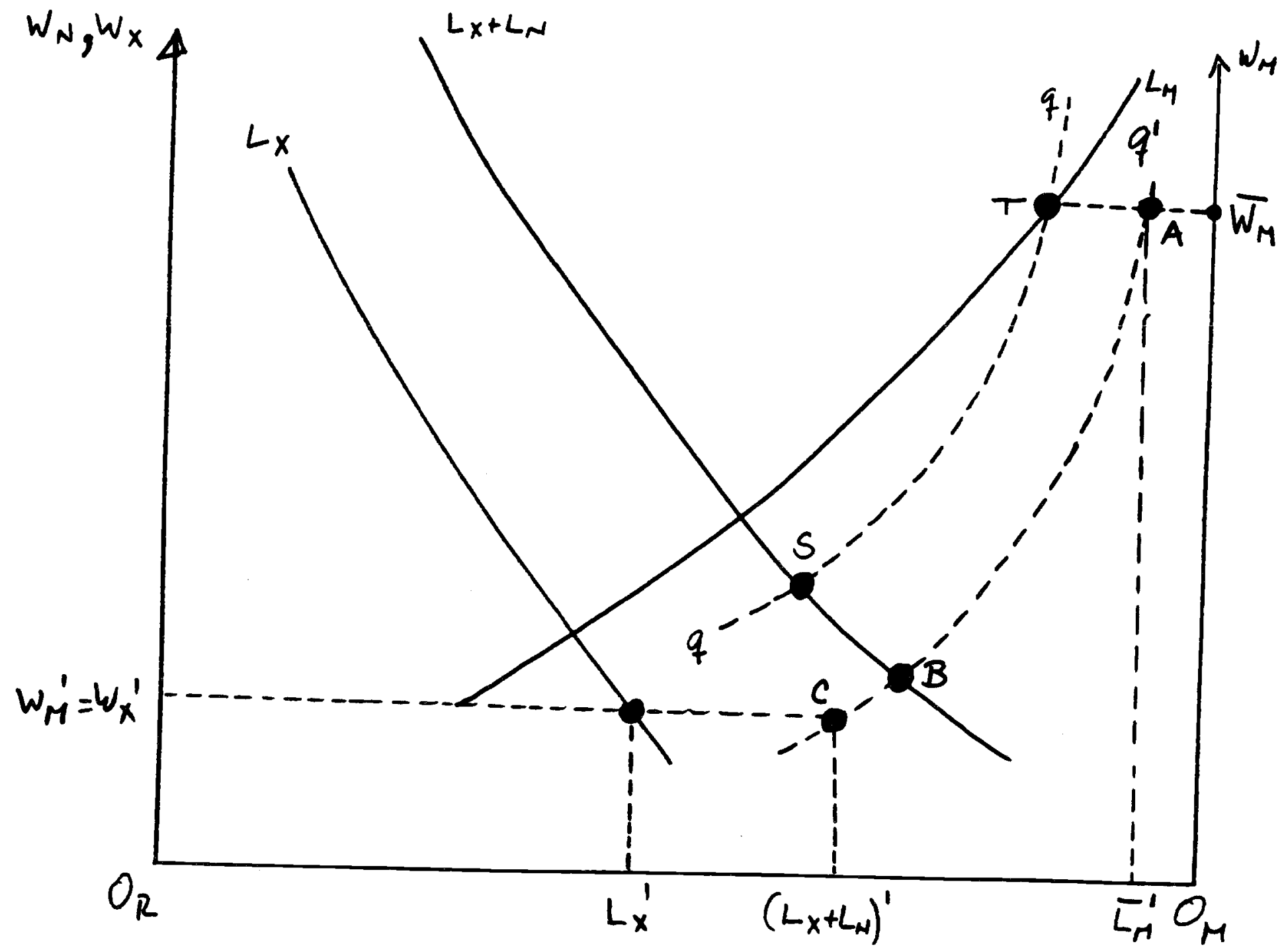


$M$ the demand for labor in that sector shifts downward. At the given minimum wage, $\overline{\mathrm{W}}_{M}$, the total demand for labor in the importable sector will decline. The new demand for labor in the importable sector (not drawn) intersect $\overline{\mathrm{W}}_{M} T$ at $A$. Now labor demanded by $M$ is reduced to ${ }_{M} L_{M}^{\prime}$. Naturally, a new rectangular hyperbola $q^{\prime} q^{\prime}$ goes through A.

What will happen to wages and employment in the uncovered sector, and to unemployment? In order to analyze this assume first that the price of $N$ remains constant. This assumption is relaxed later. Under a constant $P_{N}$, curve $\left(\mathrm{L}_{\mathrm{X}}+\mathrm{L}_{\mathrm{N}}\right)$ remains at its original location and point $\mathrm{B}$, given by the intersection of $q^{\prime} q^{\prime}$ and $\left(L_{X}+L_{N}\right)$ give us our new equilibrium, which is characterized by a lower wage in the uncovered sectors and higher employment in $\mathrm{N}$ and $\mathrm{X}$. However, as discussed above the improvement in the terms of trade will affect $P_{N}$, and $\left(L_{X}+L_{N}\right)$ will not remain constant. Under the assumptions discussed in Section II. 2 above, the improvement in the terms of trade generates a reduction in $P_{N}$, which is, however, smaller than the decline in $P_{M}$. As a result of this in the final short-run equilium $\left(L_{X}+L_{N}\right)$ will shift downward to $\left(\mathrm{L}_{\mathrm{X}}+\mathrm{L}_{\mathrm{N}}\right)^{\prime}$ which is not drawn. The intersection of this new $\left(\mathrm{L}_{\mathrm{X}}+\mathrm{L}_{\mathrm{N}}\right)^{\prime}$ and the $\mathrm{q}^{\prime} \mathrm{q}^{\prime}$ rectangular hyperbola give us the final equilibrium when capital is locked in its sector of origin, depicted in Figure 8 by point $C$. Under our assumptions the post terms of trade shock equilibrium is characterized by: (i) lower employment in the sector covered by the minimum wage (importables); (ii) lower wages in the uncovered sector, expressed in terms of exportables; (iii) either higher or lower equilibrium unemployment; (iv) either lower or higher employment in nontradables; (v) higher employment and production 
inexportables. $^{11}$

Not surprisingly this case of partial minimum wage coverage generates very different results than the case of an economy wide minimum wage discussed above. First, we now have an increase in production and employment in exportables. Second it is possible that under our partial coverage case employment in nontradables will also increase. Also, in this case a positive terms of trade shock may generate smaller unemployment in the short run, whereas in the case of an economy wide minimum wage greater unemployment always resulted in the short run as a consequence of a decline in $P_{M}^{*}$. This illustrates an important result: in the presence of labor market distortions exogenous shocks usually considered beneficial may generate nontrivial (short run) unemployment problems.

What will happen in the long run in this case with sector specific minimum wage? In the short run, after the world price of imports has gone down, the real return to (sector specific) capital will be different across sectors. The terms of trade shock reduces the return to capital in the manufacturing (importables) sector and increases it in the exportables and nontradables sector. Of course, this situation with different real returns to capital cannot go on in the long run. As time goes by, capital will be reallocated, moving out of the manufacturing and into the other sectors. In terms of Figure 8, this means that $L_{M}$ will shift down - - and with it the rectangular hypoerbola qq -- while the demand for labor in the uncovered sectors will shift upwards. Moreover, we know that these curves will shift in a way such that the final outcome will be characterized by a higher wage

${ }^{11}$ In this setting unemployment is given by $U=L_{M}\left(\bar{W}_{M} / W_{N}-1\right)$. Since which way $U$ will go. $\mathrm{W}_{\mathrm{N}}$ goes up, it is not posssible to know a priori in of $\mathrm{L}_{\mathrm{X}}, \mathrm{L}_{\mathrm{M}}$ and $\mathrm{L}_{\mathrm{N}}$. 
in the absence of wage rigidities. The final long run equilibrium will have to satisfy both the condition that the return to capital is equalized across sectors and that the labor market is in equilibrium, in the sense that $W_{N}=$ $\mathrm{W}_{\mathrm{X}}=\left(\mathrm{L}_{\mathrm{M}} /\left(\mathrm{L}_{\mathrm{M}}+\mathrm{U}\right)\right) \overline{\mathrm{W}}_{\mathrm{M}}$. As capital is reallocated, employment in $\mathrm{M}$ declines and employment in $X$ and $N$ increases in relation to their short run levels depicted in Figure 8. However, it is not possible to know a priori whether in the long run the wage rate in the uncovered sectors $N$ and $X$ will be higher or lower than their initial level. This will depend on the elasticities of substitution and on the relation between the slope of the $\mathrm{L}_{\mathrm{M}}$ curve and the $\mathrm{qq}$ and $\mathrm{N}$.

IV. Imported Intermediate Inputs, Devaluation and Employment In the preceding sections we have expanded the standard trade model to the case of three goods, and four factors to analyze the effects of external shocks on the sectoral allocation of employment, wages and unemployment. Following the traditional approach the discussion above assumed away the existence of imported intermediate inputs and ignored any complications stemming from macroeconomic aspects. Recently, however, a more macrooriented literature that analyzes the relation between devaluations and aggregate employment has emerged. In this literature external shocks not only affect the sectoral allocation of a given total level of employment but can also affect the total level of employment. Moreover, according to this literature, and contrary to the traditional view, devaluations will likely result in a drop in employment and output (van Wijnbergen 1986). In this section we discuss this issue in some detail. For this purpose we first formally develope a stylized model of a small open economy that produces three goods, and uses imported inputs in the production of home or 
nontradable good. We then discuss briefly the existing empirical evidence in this area.

\section{IV.1 Devaluation. Aggregate Output and Employment}

In this section we develop a model to analyze the effects of nominal devaluations on aggregate output and employment in a small country. The model analyzes the case of an economy that produces three goods and uses imported inputs in the production of the nontradables, and is sufficiently general as to include the models of Cooper (1971b), Krugman and Taylor (1978), Hanson (1983) and Branson (1986) as special cases. Although the analysis concentrates on the case of a devaluation, the model can easily handle the case of a terms of trade shock.

Consider, as in Section II, a small country that produces exportables, importables and nontradable goods. The capital stock is sector specific and fixed during the relevant run discussed here. ${ }^{12}$ The production of nontradables requires the use of labor, (specific) capital and an imported input. However, in order to simplify the exposition it is assumed that exportables and importables are produced using capital and labor only. It is also assumed that this country has a stock of foreign debt, whose nominal value in foreign exchange is equal to $D *$. As is usually the case in the developing countries $\ddot{i t}$ is assumed that due to institutional reasons the labor market does not clear, and that the behavior of nominal wages is governed by an indexation rule that ties changes in wages to changes in the price level.

In order to simplify the exposition, and to focus on the effects of devaluations on output and employment, it is assumed that world prices of $X$ 12 As will become apparent below the assumption of mobile capital will
greatly complicate the analysis. 
and $M$ are constant. As will be seen below, however, the model can be easily manipulated to analyze effects of changes in the external terms of trade on output and employment.

The model is given by equations (1) through (9):

$$
\begin{aligned}
& y=H^{S}+\frac{e P_{X}}{P_{H}} x^{S}+\frac{e P_{M}}{P_{M}} M^{S}-\frac{e P_{1}}{P_{H}} I-\frac{e i * D *}{P_{H}} \\
& H^{d}=H\left(y, \frac{P_{H}}{e P_{M}}, \frac{P_{H}}{e P_{X}}, \frac{B}{P_{H}}\right)+G \\
& \mathrm{H}^{\mathrm{S}}=\mathrm{k}\left[\beta \mathrm{I}^{-\rho}+(1-\beta) \mathrm{V}^{-\rho}\right]^{-1 / \rho} \\
& V=L_{H}^{\gamma} \bar{K}_{\mathrm{H}}^{(1-\gamma)} \\
& \mathrm{X}^{\mathrm{S}}=\mathrm{L}_{\mathrm{X}}^{\theta} \overline{\mathrm{K}}_{\mathrm{X}}^{(1-\theta)} \\
& M^{S}=L_{M}^{\delta} \bar{K}_{M}^{(1-\delta)} \\
& \mathrm{W}=\mathrm{C}_{0} \exp (\omega \mathrm{P}) \\
& P=P_{H}^{a_{1}}\left(e P_{X}\right)^{a_{2}}\left(e P_{M}\right)^{\left(1-a_{1}-a_{2}\right)} \\
& H^{d}=H^{S}
\end{aligned}
$$

where the following notation is used.

y

= real income in terms of home goods;

$\mathrm{H}^{\mathrm{S}}, \mathrm{H}^{\mathrm{d}} \quad$ = supply and demand for nontradables;

$\mathrm{X}^{\mathrm{S}} \quad=$ supply of exportable goods;

$\mathrm{M}^{\mathrm{S}} \quad$ = supply of importables;

I $\quad$ imported intermediate input

$\mathrm{V}=\quad$ value added in the nontradables good sector;

$\mathrm{P}_{\mathrm{X}}, \mathrm{P}_{\mathrm{M}}, \mathrm{P}_{\mathrm{I}}=$ world prices of exportables, importables and intermediate goods expressed in terms of foreign exchange; 


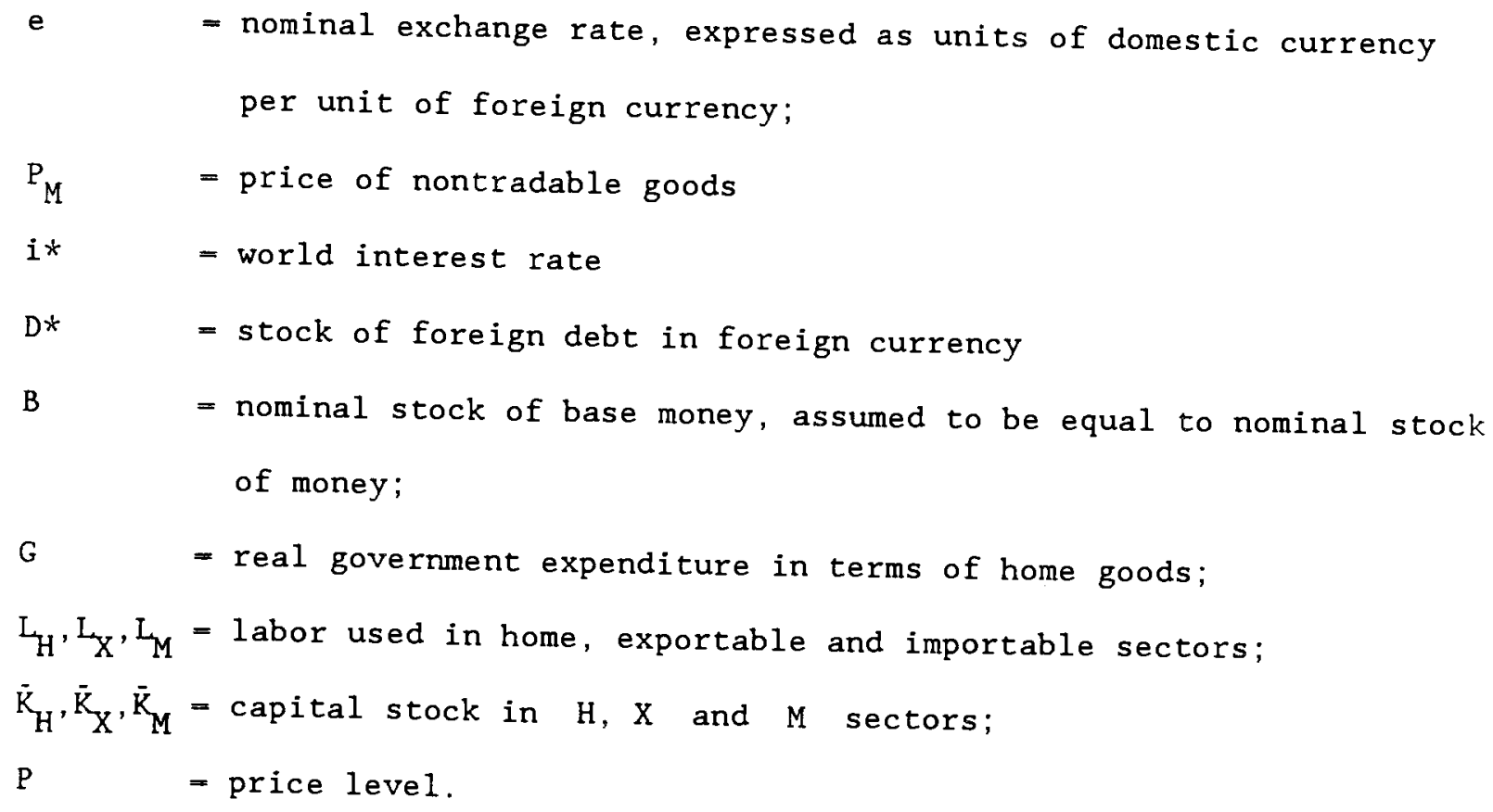

Equation (1) is real income in terms of home goods. Equation (2) is the demand function for nontradables, which is composed of the private sector demand $H$ plus the government's demand $G$. It is assumed that the private sector demand for $H$ depends on real income, relative prices and the real stock of money. Equation (3) is the production function for $H$ goods. It is a CES function with an elasticity of substitution between value added and imported inputs equal to $\sigma=(1+\rho)^{-1}$. Equation (4) specifies that value added in the nontradables sector is produced using CobbDouglas technology, and that the capital stock in that sector is fixed. Equations (5) and (6) are the production functions for $X$ and $M$, which are assumed to be Cobb-Douglas. Equation (7) is the indexation rule, and establishes that nominal wages are adjusted in a proportion $\omega$ of inflation. This equation assumes that due to institutional reasons (unions and so on) the labor market does not clear. If, on the contrary we assume full flexibility in the labor market this equation should be replaced by a 
labor supply equation. Equation ( 8 ) is the definition of the price level. From (7) and ( 8 ) we get that nominal wages are adjusted according to the following rule: $\hat{\mathrm{W}}=\omega_{1} \hat{\mathrm{P}}_{\mathrm{H}}+\omega_{2} \hat{\mathrm{e}}$, where $0 \leq\left(\omega_{1}+\omega_{2}\right) \leq 1$. Finally, equation (9) establishes that in equilibrium the nontradable goods market clears. This model is quite general and differs from previous work in various respects. First, contrary to Cooper (1971c), Krugman and Taylor (1978) and Hanson (1983), the current model specifically includes a supply side. In the models of Krugman and Taylor (1978), Taylor (1978), and Hanson (1983), the supply side is replaced by the assumption of markup pricing in the nontradables good sector (see below). Second, contrary to Krugman and Taylor (1978), Gylfason and Schmidt (1983), Gylfason and Radetzki (1984), Hanson (1983), and Branson (1986) in the current model households are allowed to consume all three goods. Third, the current model also incorporates the existence of external debt. In the discussion that follows it will be pointed out how this model can be simplified to generate as special cases the approaches previously discussed in the literature.

Our interest is to find out the effect of a devaluation (i.e., increase in e) on total employment and output in this economy. For this purpose we first derive the demand for labor functions.

Assuming profit maximization and perfectly competitive firms we can obtain from equations (3), (4), (5) and (6) the demand functions for imported inputs and labor in each sector:

$$
\begin{aligned}
& I=A_{0}\left(P_{H} / e P_{I}\right)^{\sigma} H, \\
& L_{H}=A_{1}\left(P_{H} / W\right)^{1 /[1+\gamma(1-\sigma) / \sigma]} H^{1 / \sigma[1+\gamma(1-\sigma) / \sigma]}, \\
& L_{X}=\theta\left(e P_{X} / W\right) X \\
& L_{M}=\delta\left(e P_{M} / W\right) M,
\end{aligned}
$$


where $A_{0}$ and $A_{1}$ are constants.

In order to find out how changes in $e$ affect total real output and employment, it is first necessary to investigate the way in which devaluations affect the nontradable goods market. From equations (1), (2), (7) and (11), and using expressions for the supply functions of $X$ and $M$ obtained from (5), (6), (12), and (13), we can derive the following equation for the rate of change of the demand for $H$ (where as customary, $\hat{x}=(d X / d t)(1 / x)$.

$$
\hat{H}^{d}=D_{1} \hat{e}+D_{2} \hat{P}_{H}+D_{3} \hat{B}+D_{4} \hat{G}
$$

where the $D^{\prime}$ s are given by:

$$
\begin{aligned}
& \mathrm{D}_{1}=\mathrm{Q}\left[\left(\lambda_{\mathrm{X}}+\lambda_{\mathrm{M}}\right)+\left(\eta_{\mathrm{X}} \epsilon_{\mathrm{X}}+\lambda_{\mathrm{M}} \epsilon_{\mathrm{M}}\right)\left(1-\omega_{2}\right)-\left(\eta_{\mathrm{X}}+\eta_{\mathrm{M}}\right) / \phi-\lambda_{1}(1-\sigma)-\lambda_{\mathrm{D}}\right] \\
& \left.\mathrm{D}_{2}=\mathrm{Q}\left[\left(\lambda_{\mathrm{X}}+\lambda_{\mathrm{M}}\right)-\left(\eta_{\mathrm{X}}+\eta_{\mathrm{M}}\right) / \phi+\mu / \phi+\left(\epsilon_{\mathrm{X}} \lambda_{\mathrm{X}}+\epsilon_{\mathrm{M}}{ }_{\mathrm{M}}\right) \omega_{1}-\lambda_{\mathrm{I}}(1-\sigma)-\lambda_{\mathrm{D}}\right)\right] \\
& \mathrm{D}_{3}=\mu / \mathrm{Q} \\
& \mathrm{D}_{4}=\mathrm{G} / \mathrm{HQ}
\end{aligned}
$$

and

$Q=\phi /\left[1-\phi\left(1-\left(\lambda_{X}+\lambda_{M}-\lambda_{D}\right)\right)\right]$.

Where $\phi=\left(\mathrm{H}^{\mathrm{P}} / \mathrm{H}\right) \eta_{\mathrm{y}}$, for $\left(\mathrm{H}^{\mathrm{P}} / \mathrm{H}\right)$ ratio of private to total demand for $H$ and where $\eta_{y}$ is the income elasticity of demand for $H . \lambda_{X}, \lambda_{M}, \lambda_{I}, \lambda_{D}$ are ratios of exports, imports, imported inputs and debt payments to total real income (i.e., $\lambda_{\mathrm{X}}=\left(\mathrm{e} \mathrm{P}_{\mathrm{X}} \mathrm{X}\right) /\left(\mathrm{P}_{\mathrm{H}} \mathrm{y}\right)$ ). $\eta_{\mathrm{X}}$ and $\eta_{\mathrm{M}}$ are the price elasticities of demand for $H$ with respect to $P_{H} / P_{X}$ and $P_{H} / P_{M}$, and consequently are negative. $\epsilon_{X}$ and $\epsilon_{M}$ are the price elasticities of supply for $X$ and $M$ (i.e., $\left.\epsilon_{X}=\theta /(1-\theta)>0, \epsilon_{M}=\delta /(1-\delta)>0\right) . \quad \mu$ is the demand elasticity of $H$ with respect to real cash balances. Stability requires that $Q>0$. Moreover, in order for the (total) demand elasticity of $H$ with respect to its (nominal) price to be negative it is needed that: $\left[\left(\lambda_{X}+\lambda_{M}\right)\left(1-W_{1}\right)-\left(\eta_{X}+\eta_{M}\right) / \phi+(\mu / \phi)\right]>\lambda_{D}+(1-\sigma) \lambda_{I}$. In fact, throughout the 
rest of the analysis we will assume that this is indeed the case.

As may be seen from equation (14), when there is a devaluation (i.e., an increase in $e$ ), the demand for nontradables is subject both to expenditure reducing and expenditure switching effects. Moreover, it is clear from equation (14) that with other things given, a (nominal) devaluation can either generate an increase or decline in the demand for nontradables, depending on whether $\left[\left(\lambda_{M}+\lambda_{X}\right)\left(1-\omega_{2}\right)+\lambda_{X} \epsilon_{X}+\lambda_{M} \epsilon_{M}-\right.$ $\left.\left(\eta_{\mathrm{X}}+\eta_{\mathrm{M}}\right) / \phi\right] \gtrless \lambda_{I}(1-\sigma)+\lambda_{\mathrm{D}}$. If $\mathrm{D}_{1}<0$, then the expenditure reduction effect dominates. Notice however, that given our assumption that $D_{2}<0$, the more plausible case will indeed be that $D_{1}>0$.

In this case the expenditure switching effect will dominate and the devaluation will result in a higher demand for $H$. With respect to $D_{3}$ and $\mathrm{D}_{4}$, with other things given, higher money and government expenditures will generate increases in the demand for $H$.

It is interest to note that equation (14) includes, as special cases, a number of previous models. For example, if $\epsilon_{\mathrm{X}}=\epsilon_{\mathrm{M}}=\omega_{1}=\omega_{2}=\lambda_{D}=0$ and $\hat{\mathrm{P}}_{\mathrm{H}}=\mathrm{vê}$ (i.e., there is markup pricing for home goods), equation (14) corresponds to Hanson's model. Moreover, if in addition we assume that $\lambda_{M}=\sigma=0$ equation (14) becomes equivalent to the model by Krugman and Taylor (1978).

Let us now turn to the supply side for home goods. From the first order conditions (10) and (11) we obtain expressions for $\hat{I}$ and $\hat{L}_{H}$, and using the wage indexation equation (7) to eliminate $\hat{W}$, to finally obtain the following equation for changes in the supply for nontradable goods.

$$
\hat{\mathrm{H}}^{\mathbf{s}}=\mathrm{S}_{1} \hat{\mathrm{P}}_{\mathrm{H}}+\mathrm{S}_{2} \hat{\mathrm{e}}
$$

where: 


$$
\begin{aligned}
& S_{1}=\left(\frac{1}{1-\gamma}\right)\left\{\frac{\pi_{1}}{\pi_{2}}(\sigma(1-\gamma)+\gamma)+\gamma_{1}\left(1-\omega_{1}\right)\right\} \\
& S_{2}=-\left\{\frac{\sigma(1-\gamma)+\gamma}{1-\gamma}\right\}\left[\pi_{2} / \pi_{2}+\gamma W_{2}\right] .
\end{aligned}
$$

From (15) it is possible to see that, with other things given, an increase in $P_{H}$ generates an increase in the supply of home goods, while a devaluation will shift the aggregate supply curve upward and to the left. The channel through which this happens is the effect of the devaluation on the price of the imported intermediate input.

Combining (14) and (15) we can obtain final expressions for $\hat{\mathrm{H}}$ and $\hat{\mathrm{P}}_{\mathrm{H}}$ :

$$
\begin{aligned}
& \hat{H}=\left\{\frac{D_{2} S_{2}-D_{1} S_{1}}{D_{2}-S_{1}}\right\} \hat{e}-\left\{\frac{D_{3} S_{1}}{D_{2}-S_{1}}\right\} \hat{B}-\left\{\frac{D_{4} S_{1}}{D_{2}-S_{1}}\right\} G \\
& \hat{P}_{H}=\left\{\frac{S_{2}-D_{1}}{D_{2}-S_{1}}\right\} \hat{e}-\left\{\frac{D_{3}}{D_{2}-S_{1}}\right\} \hat{B}-\left\{\frac{D_{4}}{D_{2}-S_{2}}\right\} \hat{G}
\end{aligned}
$$

From (16) it follows that:

$$
\begin{aligned}
& (\hat{\mathrm{H}} / \hat{\mathrm{e}}) \gtrless 0 \\
& (\hat{\mathrm{H}} / \hat{\mathrm{B}})>0 \\
& (\hat{\mathrm{H}} / \hat{\mathrm{G}})>0 .
\end{aligned}
$$

Whether a devaluation will reduce or not output of home goods will depend on $\left(D_{2} S_{2}-D_{1} S_{1}\right) \gtrless 0$. A sufficient condition for having a contractionary devaluation is that $D_{1}<0$. That is the case where a devaluation shifts back both demand and supply for $H$. However, under the more plausible case where the expenditure switching effect dominates in (14) (i.e., $D_{1}>0$ ), and a devaluation increases the demand for nontradables, there will be two 
forces that will operate in the opposite directions. In this case the effect of a devaluation on $H$ will be ambiguous. In fact they will pretty much be an empirical question.

The effects of a devaluation on the levels of sectoral employment is obtained from equations (11), (12), (13), (16) and (17):

$$
\begin{array}{r}
\hat{\mathrm{L}}_{\mathrm{H}} / \hat{\mathrm{e}}=\left[\frac{1}{\sigma(1-\gamma)+\gamma}\right]\left[\left(\frac{1}{\mathrm{D}_{2}-\mathrm{S}_{2}}\right)\left(\mathrm{D}_{2} \mathrm{~S}_{2}-\mathrm{D}_{1} \mathrm{~S}_{1}+\left(1-\omega_{1}\right) \sigma\left(\mathrm{S}_{2}-\mathrm{D}_{1}\right)-\omega_{2} \sigma\right] \gtrless 0\right. \\
\hat{\mathrm{L}}_{\mathrm{X}} / \hat{\mathrm{e}}-\left[\left(1-\omega_{1}\right)+\left(\frac{\phi}{1-\phi}\right)\left(1-\omega_{2}\right)-\left(\frac{\omega_{1}}{1-\phi}\right)\left(\frac{\mathrm{S}_{2}-\mathrm{D}_{1}}{\mathrm{D}_{2}-\mathrm{S}_{1}}\right)\right] \gtrless 0 \\
\hat{\mathrm{L}}_{\mathrm{M}} / \hat{\mathrm{e}}=\left[\left(1-\omega_{1}\right)+\left(\frac{\delta}{1-\delta}\right)\left(1-\omega_{2}\right)-\left(\frac{\omega_{1}}{1-\delta}\right)\left(\frac{\mathrm{S}_{2}-\mathrm{D}_{1}}{\mathrm{D}_{2}-\mathrm{S}_{1}}\right)\right] \gtrless 0 .
\end{array}
$$

Again, the signs of these elasticities are ambiguous; the final effect of a devaluation on employment will depend on the relative strength of the different effects involved. These, in turn will be a function of the different elasticities. While the inability to determine unequivocally these signs is somewhat frustrating, this analysis is very useful in that it makes clear that contrary to the more traditional views, in more realistic models with imported intermediate inputs and foreign debt, a devaluation can be contractionary, and reduce the level of employment. Whether this is indeed an important case is an empirical question. In the next section we briefly review the existing attempts to empirically test whether devaluations are contractionary or expansionary.

Notice that the analysis presented here can be easily extended to the case of a terms of trade shock. In particular an increase in the world price of the intermediate import will be in many ways (but not all) similar to the devaluation case discussed here. 
IV. 2. Devaluation and Economic Activity: The Empirical Evidence

As shown above, there are a number of channels through which devaluations can negatively affect the level of aggregate output and employment in an open economy. In spite of the renewed theoretical interest on the possible contractionary effects of devaluations, the empirical analysis has been somewhat sketchy. Moreover all of these studies have looked at the effects of devaluations on aggregate real output, rather than on employment. 13

A number of studies have used cross country data to simulate the effects of devaluations on real output. Gylfason and Schmidt (1983) have constructed a small macromodel with intermediate goods, where a devaluation has two conflicting effects: on one hand it generates an expansion through aggregate demand; on the other hand, a devaluation results, through its effect on the cost of imported intermediate inputs, in an upward shift in the aggregate supply schedule. The final effect of a devaluation can be either expansionary or contractionary. Gylfason and Schmidt empirically analyze the implications of their model by imputing plausible values to the corresponding parameters for a group of five developed countries and five developing countries. With the exceptions of the U.K. and Brazil their results suggest that, as postulated by the more traditional views, devaluations have a positive overall effect on aggregate output.

Conolly (1983) considered a group of 22 countries and regressed for the cross-country data set the change in the rate of real growth on the change in the nominal exchange rate. The coefficient obtained was positive and

13 The reason for this, of course, is that for the developing countries
data on aggregate output are much more reliable than the employt the data on aggregate output are much more reliable than the employment
data. 
marginally significant, providing some support to the hypothesis of expansionary devaluations. However, Conolly argues that his results are subject to a selectivity bias, since typically countries that devalue do so after having entered into a recession.

Gylfason and Risager (1984) developed a model for a small country, which stresses the effect of devaluations on interest payments on the foreign debt. Using imputed parameter data they find that while devaluations are generally expansionary in developed countries, in developing countries they are likely to be contractionary. However, a problem with this type of approach is that the parameters used in the simulation are obtained from very different sources, and are likely to be inconsistent among themselves.

Gylfason and Radetzki (1985) developed a small macromodel to investigate the effects of devaluations on real output, the current account, and real wages. They show that in a world with no capital movements, in order for a devaluation to result in higher real output, real wages necessarily have to fall. They then show that if a devaluation is accompanied by an inflow of foreign funds, it is possible for real output to increase with unchanged real wages. Gylfason and Radetzki use a group of 12 poor countries to simulate their model. As in other papers, in the simulation analysis they use imputed values for the parameters. Their results suggest that, for their group of countries, with nominal wages constant and no capital inflows a $10 \%$ devaluation will result in a decline of real GNP of 0.58 .

Other authors have constructed country-specific simulation models to analyze the effectiveness of devaluations as stabilization policy tools. Branson (1986), for example, has recently constructed a small simulation 
model for Kenya to investigate these issues. His results suggest that, contrary to the traditional view, a devaluation will have important contractionary effects in the Kenyan economy. Taylor and Rosenweig (1984), on the other hand, built a fairly large computable general equilibrium model for Thailand, and simulated the effects of a number of policy measures, including a devaluation, on the Thai economy. Their results indicate that a devaluation of the baht of $10 \%$ will have an expansionary effect and will generate an increase in real GDP of 3.38 .

Other studies have discussed the output effects of devaluations in a less formal way. Cooper (1971a), in his well-known study, analyzed 24 devaluations that took place between 1953 and 1966. After looking at the behavior of the principal components of aggregate demand he concluded that "devaluation itself often initially tends to depress economic activity in the devaluing country, contrary to what has normally been expected" ( $p$. 504). Krueger (1978) analyzed output behavior during the periods surrounding major devaluation episodes in the countries considered in the NBER project on trade liberalization. She found that in most cases devaluations had been associated with expansions in the level of real activity. Also, the numerous studies that have investigated the effects of IMF stabilization programs on output havë looked at real activity behavior before and after major devaluations. Most of these studies have used a "before" and "after" approach and found that nominal devaluations had not been accompanied, or followed, by major declines in real activity (Gylfason 1983; Khan and Knight 1985).

In his general empirical analysis of devaluation Edwards (1987) looked in detail at the contractionary devaluation issue. This is done in two ways. First, the real activity aspects of the 30 devaluations episodes used 
in his analysis were closely scrutinized. The behavior of a number of key variables in the period elapsed between three years before the devaluation and three years after the devaluation was analyzed for all 30 devaluation episodes. Since there are no reliable data on employment for all these countries, the emphasis was placed on real aggregate output, aggregate gross investment and real growth. It was found that, by and large, the evidence was mixed, and depending on which variable one looked at, some countries experienced a fall in real activity and others experienced an increase in the level of aggregate output.

of course, as with some of the other papers, a problem with this type of analysis is that it concentrates on the behavior of the key variables "before" and "after" the devaluation, without taking into account the possible role of other policies or external events. This problem was avoided by the second approach taken in this study: an equation for aggregate output in an open economy is estimated for a group of 12 countries, using pooled data. (See also Edwards 1986c.) In addition to the possible effect of the exchange rate on output, this equation incorporates the role of monetary policy, fiscal policy and exogenous terms of trade changes. From this regression analysis it was found that, keeping other things constant, devaluations have a small contractionary effect in the short run. In the long run, however, devaluations appear to be neutral, and don't affect the level of aggregate activity, or aggregate employment. Regarding terms of trade effects, as with other previous studies, it was found that when correcting for other variables there were no statistically significant effects on the level of real output.

\section{Summary and Concluding Remarks}


This paper has provided a selective survey of several issues related to the reaction of labor markets in open economies, emphasizing the role of terms of trade and exchange rate disturbances. In Section II a three-good trade model was developed to investigate how sectoral labor allocation and wages react to shocks on world terms of trade. The analysis looked at both the short- and, long-run and in the tradition of standard trade theory assumed that total labor supply is given. Assuming flexible wages it is shown that in the short run labor will move to a particular sector, only to move out of it in the longer run. This brings up the issue of transaction costs and the role of expectations in determining labor movements. Section III introducee wage rigidities in the form of either an economy-wide minimum wage or a sector specific minimum wage. It was shown that even if importables are capital intensive, and the minimum wage is expressed in terms of the exportable good, a positive terms of trade shock will generate unemployment in the short run. The labor market reaction will depend, however, on coverage of the minimum wage.

In Section IV a model of a small economy that produces three goods and uses imported intermediate inputs in the production of nontradables was developed to investigate the effects of devaluation on employment. It was shown that, contrary to the traditional view, in this setting devaluations can result in a contraction in output and employment. Whether this contractionary result will actually take place will depend on a number of parameters, including the elasticity of substitution between importables and value added, and the importance of foreign debt. In this section we also review the empirical literature on the relation between devaluations, terms of trade and aggregate activity. 


\section{REFERENCES}

Branson, William H. "Stabilization, Stagflation and Investment Incentives: The Case of Kenya 1975-80" in S. Edwards and L. Ahmed (eds.) Economic Adjustment and Exchange Rates in Developing Countries. University of Chicago Press, 1986.

Brecher, R.A. "Minimum Wage Rates and the Theory of International Trade." Quarterly Journal of Economics (1974): 98-116.

Bruce, N. and D. Purvis. "The Specification of Goods and Factor Markets in Open Economy Macroeconomic Models" in R.W. Jones and P.B. Kenen (eds.) Handbook of International Economics. North Holland, 1984.

Cooper, Richard. "Currency Devaluation in Developing Countries" in G. Ranis (ed.) Government and Economic Development. New Haven, CT: Yale University Press, 1971a.

"Currency Depreciation in Developing Countries." Princeton Essays in International Finance 86 (1971b).

Conolly, Michael. "Exchange Rates, Real Economic Activity and the Balance of Payment" in E. Classen and P. Sahlin (eds.) Recent Issues in the Theory of Flexible Exchange Rates. North-Holland, 1983.

Corden, W.M. and R. Findlay. "Urban Unemployment, Intersectoral Capital Mobility and Development Policy." Economica 42 (1975): 59-78.

and J.P. Neary. "Booming Sector and De-Industrializa5tion in a Smal1 Open Economy." Economic Journal (1982): 825-48.

Dornbusch, R. "Tariffs and NonTraded Goods." Journal of International Economics (1974): 117-185.

. Open Economy Macroeconomics. Basic Books 1980.

Edwards, A. Cox. "Economic Reform, External Shocks, and the Labor Market: Chile 1974-83." Paper presented at World Bank Conference on Labor Market Adjustments to Foreign Shocks, June 1986.

Edwards, Sebastian. "Minimum Wages and Trade Liberalization: Some Reflections Based on the Chilean Experience." Working Paper No. 230 , Dept. of Economics, UCLA, $1982 a$.

. "The Liberalization of the Current and Capital Accounts of the Balance of Payments" in A. Choksi and D. Papageorgion (eds.) Economic Liberalization in Developing Countries (Oxford: Blackwell 1986a).

Statistics (August 1986). 
"Economic Liberalization and the Real Exchange Rate in Developing Countries." Paper presented at the Carlos Diaz Alejandro Memorial Conference, Helsinki, August 1986. forthcoming 1987).

and A. Cox-Edwards. Monetarism and Liberalization: The Chilean Experiment. (Ballinger, 1987).

and S. van Wijnbergen. "Structural Adjustment and

Disequilibrium" in H. Chenery and T.N. Srinivasan (eds.) Handbook of Development Economics. North Holland Publishing Co., 1987).

Gylfason, T. "Credit Policy and Economic Activity in Developing Countries: An Evaluation of Stabilization Programs Supported by the IMF 1977-79." IIES Seminar Paper 268, University of Stockholm (1983).

Journal of Economics (1983).

and 0. Rislaer. "Does Devaluation Improve the Current Account." European Economic Review 25 (1984), 37-64.

and M. Radetzki. "Does Devaluation Make Sense in the Least Developed Countries?" IIES Seminar Paper 314 , University of Stockholm
(1985).

Hanson, J. "Contractionary Devaluation, Substitution in Production and Consumption, and the Role of the Labor Market." Journal of International Economics 14 (February 1983), 179-89.

Harberger, A.C. "On Measuring the Social Opportunity Cost of Labor." ILO
Review (1971).

Harris, J. and M.P. Todaro. "Migration, Unemployment and Development: A Two Sector Analysis." American Economic Review (1970).

Jones. R.J. "A Three Factor Model in Theory, Trade and History" in J. Bhagwati (ed.) Trade. Balance of Payments Growth (North-Holland, 1971).

Khan, Mohsin and Roberto Zahler. "The Macroeconomic Effects of Changes in Barriers to Trade and Capital Flows: A Simulation Analysis." IMF Staff
Papers (June 1983): 223-82.

Krugman, P. and L. Taylor. "Contractionary Effects of Devaluation." Journal of International Economics 8 (August 1978): $445-56$. Mayer, W. "Short Run and Long Run Equilibrium for a Small Open Economy."
Journal of Political Economy (1974). Melvin, James. "Production and Trade with Two Factors and Three Goods."
American Economic Review (1968): 1249-268. 
Mussa, M.L. "Tariffs and the Distribution of Income: The Importance of Factor Specificity." Journal of Political Economy (1974).

"Dynamic Adjustment in the Heckscher-Ohlin-Samuelson Model." Journal of Political Economy (1978;): 1191-203.

. "The Two Sectors Model in Terms of its Dual: A Geometric Exposition." Journal of International Economics (November 1979): 513-26. (ed.) Import Competition and Response. (University of Chicago Press, 1982): 73-120.

"The Adjustment Process and the Timing of Trade Liberalization" in A. Choksi and D. Papageorgion (eds.) Economic Liberalization in Developing Countries (Oxford: Blackwell, 1986).

Neary, Peter. "Short-Run Capital Specificity and the Pure Theory of International Trade." Economic Journal 88 (1978): 448-510.

"Dynamic Stability and the Theory of Factor-Market Distortions." American Economic Review (1978): 671-82.

"Capital Mobility, Wage Stickiness and the Case for Adjustment Assistance" in J. Bhagwati (ed.) Import Competition and Response (University of Chicago Press, 1982).

"International Factor Mobility, Minimum Wage Rates and Factor Price Equalization: A Synthesis." Quarterly Journal of Economics (1985).

van Wijnbergen, Sweder. "Exchange Rate Management and Stabilization Policies in Developing Countries" in S. Edwards and L. Ahamed (eds.) Economic Adjustment and Exchange Rates in Developing Countries (University of Chicago Press, 1986). 